\title{
SOME PROBLEMS ASSOCIATED WITH MEASUREMENT \\ OF PHYSIOLOGICAL BLOOD GASES
}

Judith Dowd, M.D. AND LeONARd C. JenKins, M.D., C.M., F.R.C.P.(C) ${ }^{*}$

\section{INTRODUCTTON}

BLOOD GaS ANALYSES have been possible for almost a century, but until approximately 15 years ago, methods for the measurement of $\mathrm{pH}, \mathrm{PCO}_{2}$ and $\mathrm{PO}_{2}$ in blood samples were cumbersome and difficult to perform. With the development of precision electrodes for blood-gas analysis, it has become possible to obtain accurate values for these parameters. Also, within the past decade, physicians have become more aware of the importance of blood-gas analysis in the assessment of the respiratory and acid-base status of their patients.

\section{Measurement of PH and Blood Gases}

\section{(I) $p H$}

The glass electrode is used for $\mathrm{pH}$ measurement (Figure 1). ${ }^{1}$ This electrode consists of two half-cells, each of which develops a potential when connected together. The reference half-cell (calomel electrode) maintains a constant potential, while the glass half-cell (or electrode) develops a potential which is proportional to the hydrogen ion concentration present in the test solution. ${ }^{2}$

The instrument is calibrated by setting the span of the electrode on two phosphate buffers of known $\mathrm{pH}$. To ensure accuracy it is important that the temperature of the apparatus be kept at $37^{\circ} \mathrm{C}$. This is accomplished by means of a circulating water jacket around the electrode.

\section{(II) $\mathrm{PcO}_{2}$}

There are two methods for determination of $\mathrm{PCO}_{2}$. (i) $\mathrm{CO}_{2}$ electrode, (ii) Astrup Interpolation Technique.

(i) $\mathrm{CO}_{2}$ Electrode (Figure 2) ${ }^{\mathrm{x}}$

This consists of a standard $\mathrm{pH}$ glass electrode over which is placed a thin film of aqueous $\mathrm{NaHCO}_{3}$. A teflon membrane separates the blood sample from the $\mathrm{NaHCO}_{3}$ solution and the electrode. $\mathrm{CO}_{2}$ diffuses across the Teflon membrane and so changes the $\mathrm{pH}$ of the bicarbonate solution. This change in $\mathrm{pH}$ is then measured by the glass electrode. ${ }^{\mathbf{3} 4}$

(ii) Astrup Interpolation Technique

This technique is based on the observation that there is a linear relationship between $\mathrm{pH}$ and $\log \mathrm{Pco}_{2}$ of any particular blood sample with $\mathrm{pH}$ falling as $\mathrm{PCO}_{2}$ increases. ${ }^{5}$ Two aliquots of the blood sample are equilibrated in a tonometer with two different gases of known $\mathrm{CO}_{2}$ concentra-

*Department of Anaesthesia, University of British Columbia and Vancouver General Hospital. 


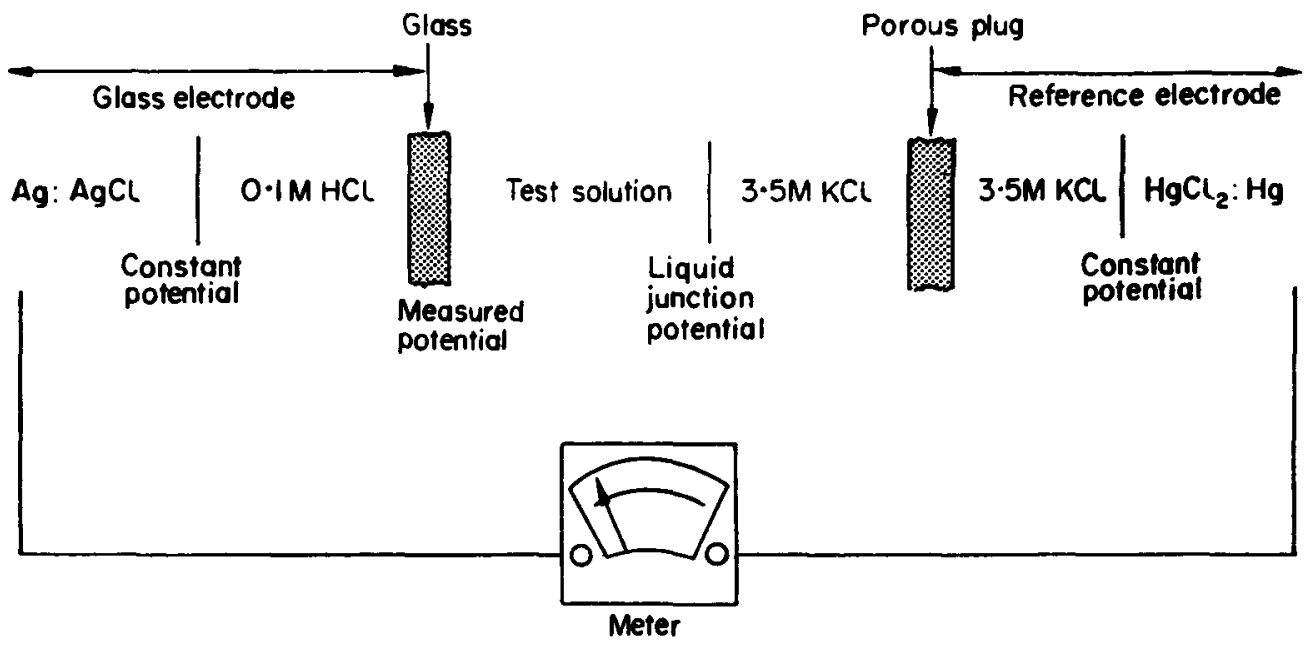

Figure 1. The measurement of $\mathrm{pH}$. Arrangement of electrodes and $\mathrm{pH}$ meter.

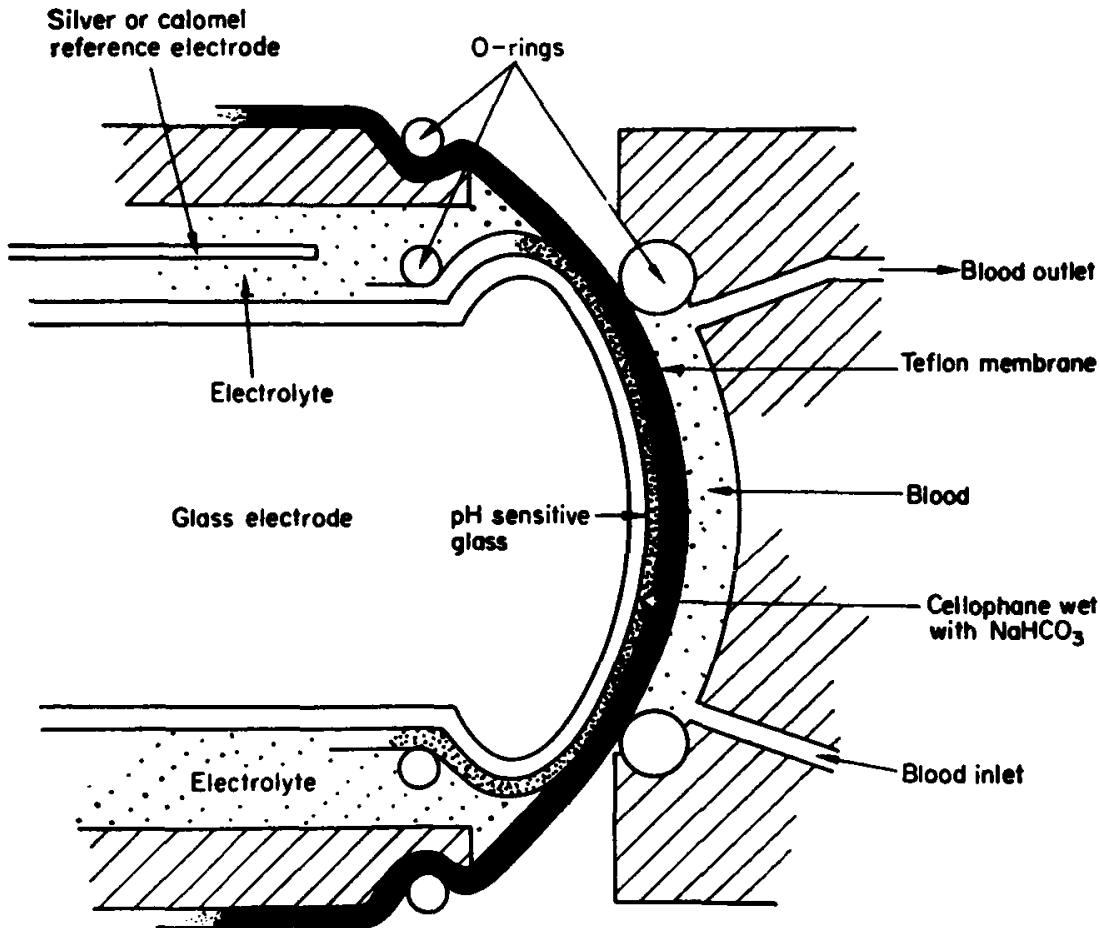

F IGURE 2. The carbon dioxide electrode.

tion, usually 4 per cent and 8 per cent $\mathrm{CO}_{2}{ }^{6}$ (Figure 3 ). ${ }^{1}$ The $\mathrm{pH}$ of each equilibrated aliquot is read with a glass electrode system, and a buffer line is drawn by plotting the $\mathrm{pH}$ readings against the relevant $\mathrm{Pco}_{2}$ values on a logarithmic scale. This represents the buffer line of that particular blood sample. The $\mathrm{pH}$ of a third aliquot of the blood sample is then interpolated in the buffer line, and the $\mathrm{PcO}_{2}$ is read off the ordinate. 


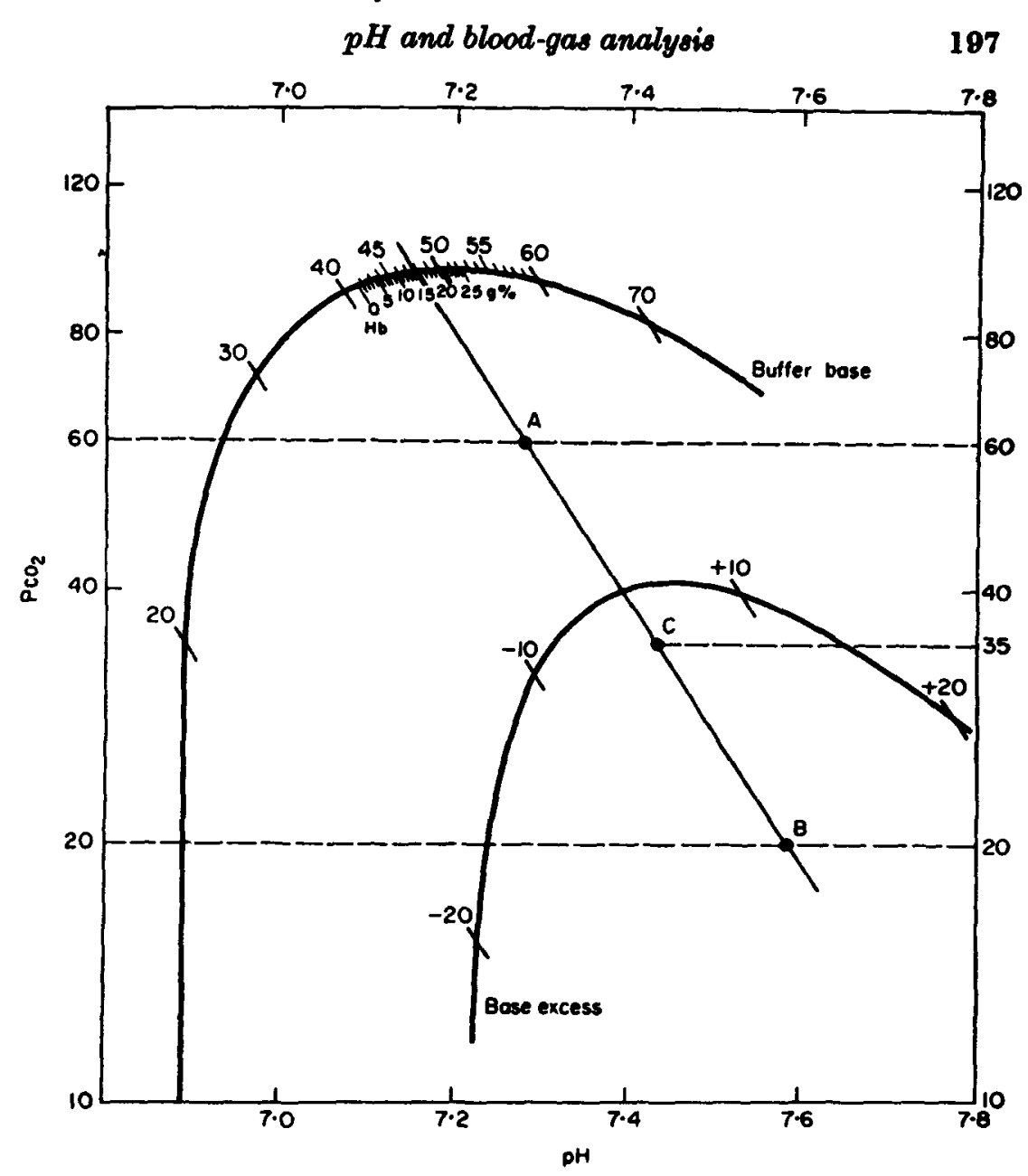

Figure 3. Siggaard-Andersen nomogram.

(III) $\mathrm{Po}_{2}$

Oxygen tension is determined by the polarographic technique, employing the Clark oxygen electrode ${ }^{7}$ (Figure 4). ${ }^{1}$ The cathode consists of a platinum wire of known diameter, sealed into a glass rod. The anode is composed of a $\mathrm{Ag} / \mathrm{AgCl}_{2}$ strip, and dips into a solution of saturated $\mathrm{KCl}$ surrounding the glass rod. ${ }^{8}$ Constant polarizing voltage of 0.5 to 0.7 volts is applied to the anode and cathode. ${ }^{4}$

The blood sample to be tested is separated from the electrode by a membrane of polyethylene or polypropylene. Oxygen from the sample diffuses across the membrane and is reduced at the cathode. This reduction reaction is balanced by oxidation at the anode, and the latter causes a current to flow between the two electrodes. The current which flows is proportional to the rate of oxygen reduction, and varies directly with the oxygen tension of the sample.

To calibrate the oxygen electrode, either gases or liquids of known $\mathrm{O}_{2}$ concentration may be used. However, since the current output of the oxygen electrode is slightly less for blood than for a gas with an identical $\mathbf{P O}_{2}$, if an electrode is 


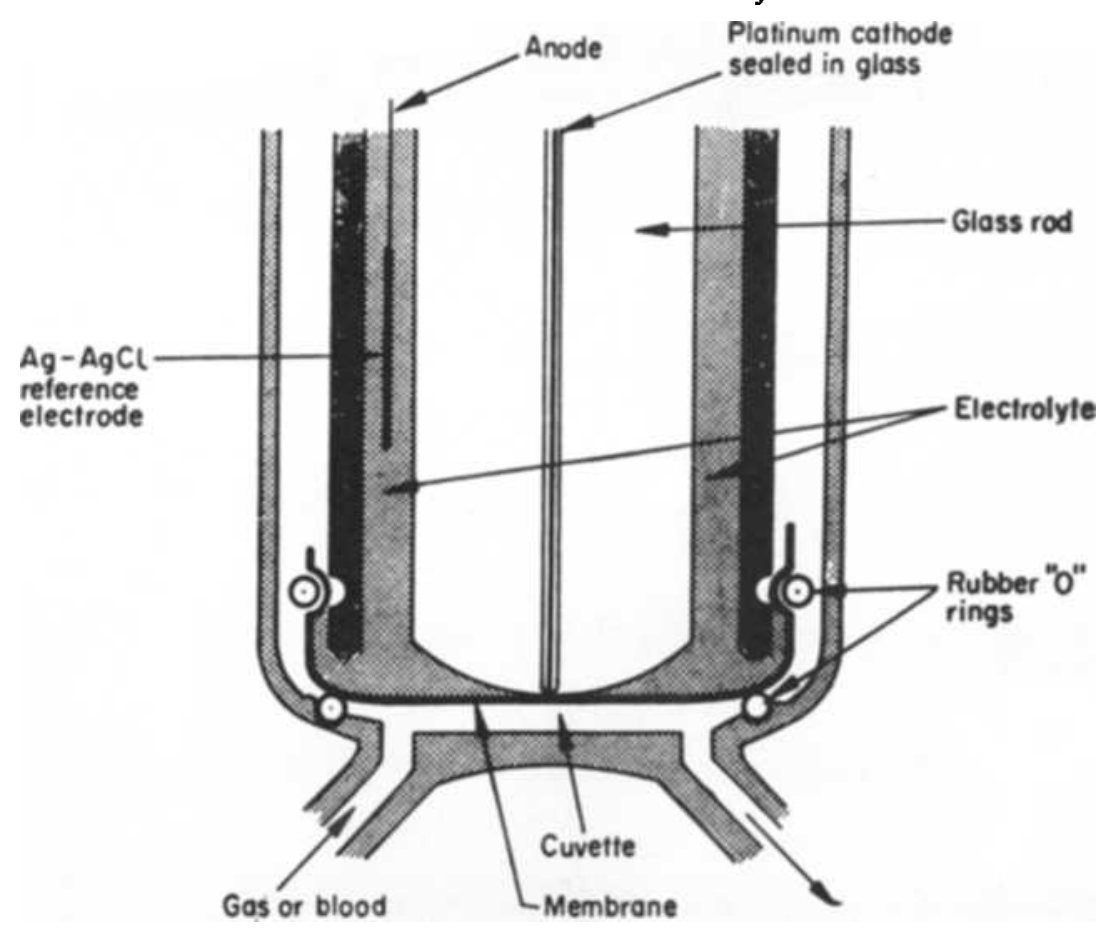

Figure 4. The oxygen electrode.

calibrated with gases, $\mathrm{Po}_{2}$ values for blood should be corrected upwards by a small factor to ensure accuracy. This correction factor is called the "blood-gas factor", and is necessary due to decreased diffusing capacity of $\mathrm{O}_{2}$ in blood as compared with gas. ${ }^{9}$

\section{PuRPose OF STUdY}

Recently it was brought to our attention that there appeared to be discrepancies in blood-gas values obtained from various laboratories at the Vancouver General Hospital, on samples obtained from the same patient at the same time. A study was thus undertaken to determine the nature of these discrepancies and to attempt to eliminate them.

There are five major areas in the hospital where blood-gas analyses are performed, involving seven machines. The areas involved were designated by letter and the methods for blood-gas analysis in each laboratory were as follows:

Area $\mathrm{A}$ ( 1 and 2): Two Radiometer machines with $\mathrm{pH}, \mathrm{PCO}_{2}$ and $\mathrm{Po}_{2}$ electrodes;

Area B: One Instrumentation Laboratory machine with $\mathrm{pH}, \mathrm{PcO}_{2}$ and $\mathrm{Po}_{2}$ electrodes;

Area C: One Beckman analyzer with $\mathrm{pH}, \mathrm{Pco}_{2}$ and $\mathrm{Po}_{2}$ electrodes;

Area D ( 1 and 2): Two Radiometer machines with $\mathrm{pH}$ and $\mathrm{Po}_{2}$ electrodes, $\mathrm{PCO}_{2}$ determined by Astrup Interpolation Technique;

Area E: One Radiometer machine with $\mathrm{pH}$ and $\mathrm{PCO}_{2}$ electrodes, $\mathrm{PCO}_{2}$ determined by Astrup Interpolation Technique. 


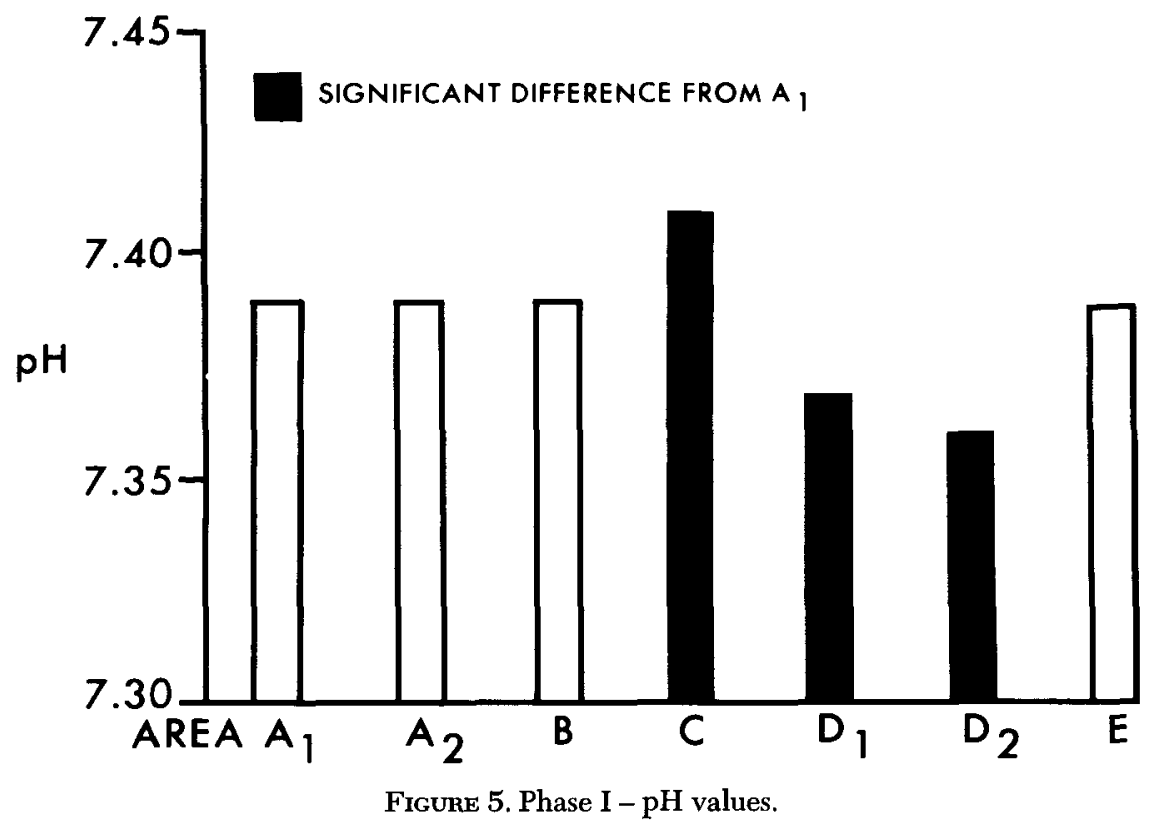

Phase I of STUdY

\section{MetHods}

Phase I of the study was carried out to determine under standard conditions whether or not significant discrepancies in values did in fact exist from area to area. Thirty blood samples were taken. Blood samples were drawn from anaesthetized patients or patients before induction of anaesthesia, or in the recovery room.

The samples were drawn from a single radial artery puncture with a \#20 needle, into a $5 \mathrm{cc}$ glass syringe heparinized from the same heparin ampoule. Care was taken to ensure anaerobic collection, and the samples were immediately placed in ice and delivered to the various laboratories. Analysis was within 30 to 45 minutes of collection, and all laboratories analyzed the sample at the same time.

Area $\mathrm{Al}$ was arbitrarily taken as the standard and results for $\mathrm{pH}, \mathrm{PCO}_{2}$ and $\mathrm{Po}_{2}$ from each other area were statistically compared with this standard, using the Student " $t$ " test. A 95 per cent confidence limit was chosen and calculated values above this level were considered statistically significant. The means of all $\mathrm{pH}, \mathrm{PcO}_{2}$ and $\mathrm{Po}_{2}$ values from each area were then plotted in bar graph form.

\section{RESULtS}

The mean $\mathrm{pH}$ values ranged from 7.36 to 7.41. The differences between Area A1 and C, D1 and D2 were statistically significant (Figure 5). However, it is doubtful whether patient therapy would be adversely affected by such differences in $\mathrm{pH}$ between areas. The mean of $\mathrm{PcO}_{2}$ values showed a wider range (from 34 to $43 \mathrm{~mm} \mathrm{Hg}$ ) (Figure 6). Again, using Area Al as the standard, there was a significant difference in means between this area and Areas B, C, DI and D2. The range of mean $\mathrm{Po}_{2}$ values was very wide from area to area ( 81 to $99 \mathrm{~mm}$ 


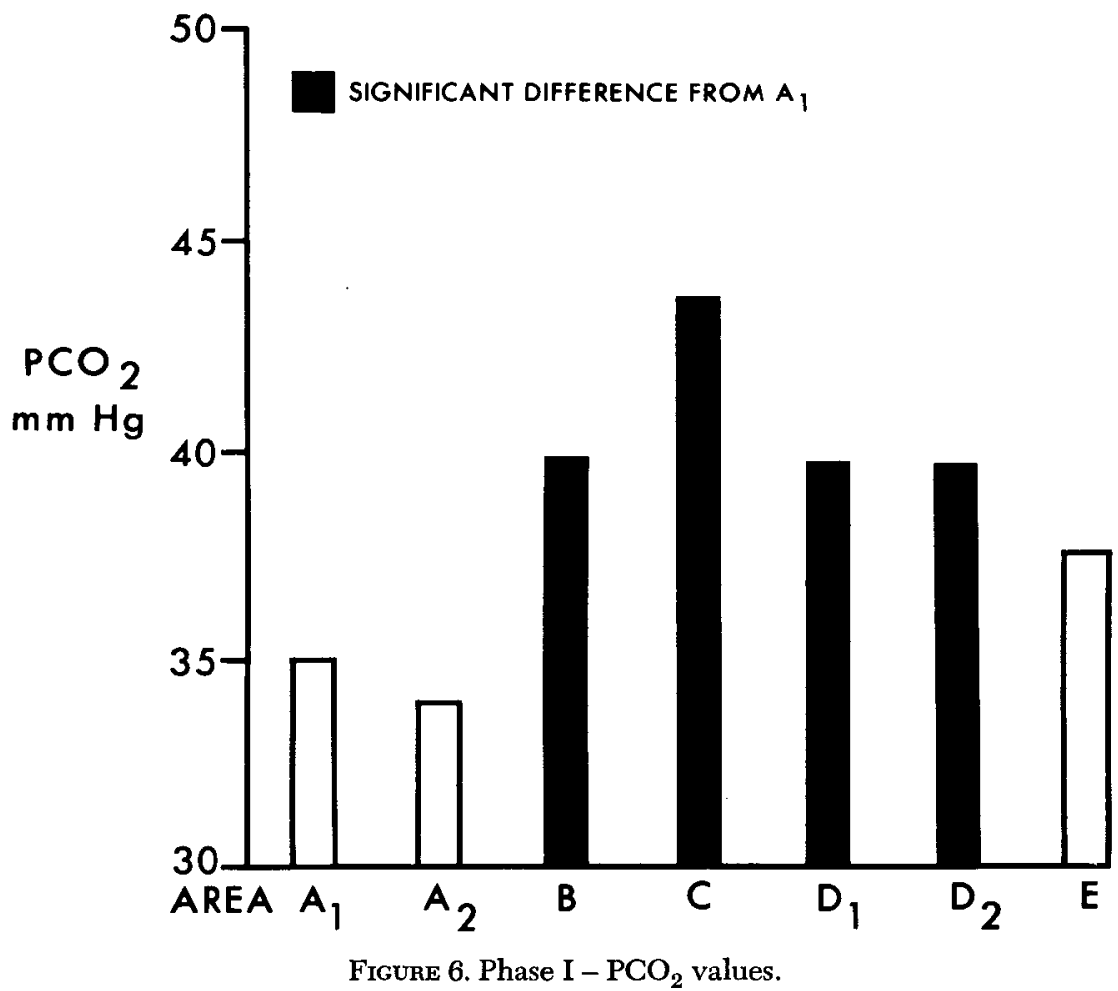

$\mathrm{Hg}$ ), with areas D1, D2 and $\mathrm{E}$ having statistically significant difference in means, as compared with the mean $\mathrm{Po}_{2}$ for Area Al (Figure 7).

Having determined that significant discrepancies did exist between areas, especially for $\mathrm{Po}_{2}$, a search for the possible causes of this discrepancy was undertaken. Investigation revealed that areas $\mathrm{A}, \mathrm{B}$ and $\mathrm{C}$ calibrated their $\mathrm{O}_{2}$ electrodes with gaseous standards (either room air or analyzed tank gases) and areas $\mathrm{D}$ and $\mathrm{E}$ calibrated with liquids - specifically, water at $37^{\circ} \mathrm{C}$ equilibrated with room air. The areas employing gas calibrations of their $\mathrm{Po}_{2}$ electrodes had not been correcting their $\mathrm{PO}_{2}$ readings for blood upwards by any blood-gas factor. Radiometer Company has stated in one of their briefs that the blood-gas factor to be employed for their $\mathrm{O}_{2}$ electrodes should be $1.03 \pm 2.0 .^{10}$ Thus, Area A, using Radiometer equipment, began to correct their blood $\mathrm{Po}_{2}$ readings upward by this factor. As well, this area changed the source of their analyzed gases. They had previously used gases analyzed by the Scholander method, but changed to tanks from another company which analyzed the gases by chromatography, which is considered to be a very accurate method of gas analysis.

Area $\mathrm{D}$ maintained the temperature of the oxygen electrode at slightly higher than $37^{\circ} \mathrm{C}$, which would tend to raise the $\mathrm{Po}_{2}$ readings. This, in turn, was corrected. We concentrated mainly on areas $A$ and $D$, since these are the two laboratories which are not autonomous; that is, they may be involved in analyzing samples from the same patient. We therefore wished to ensure that readings from these two areas were reliably consistent with one another. 


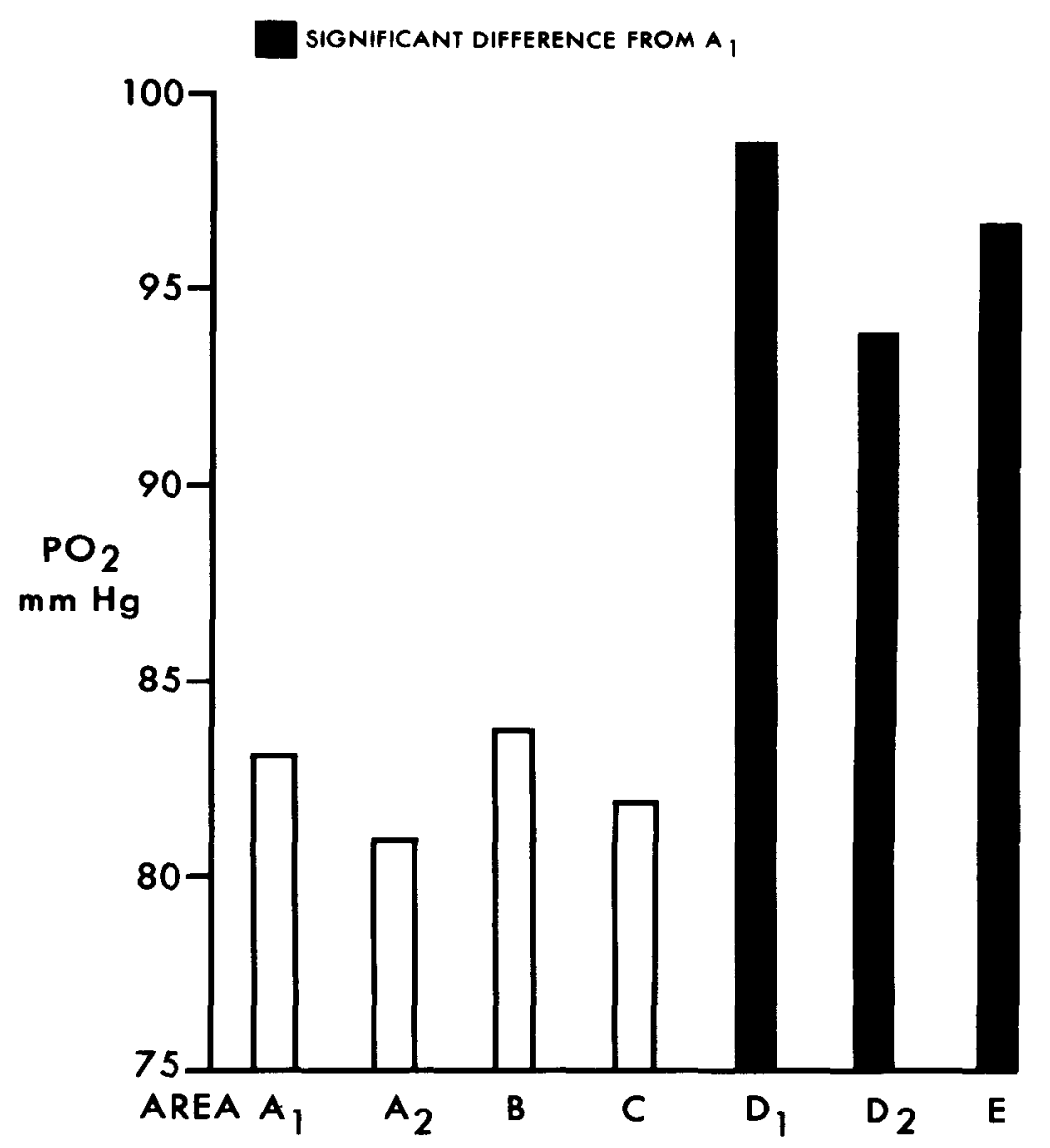

Figure 7. Phase $\mathrm{I}-\mathrm{PO}_{2}$ values.

\section{Phase II of Study}

\section{METHODS}

The second phase of the study was carried out after the corrections in Areas A and $\mathrm{D}$ were completed. A tonometer was employed. This is an apparatus used to equilibrate a blood sample with a known concentration of gases, in this case oxygen and carbon dioxide. The gases flow into a chamber containing the blood sample, which is rotated to expose a large surface of blood to the gases. At the end of the equilibration, the $\mathrm{Po}_{2}$ and $\mathrm{Pco}_{2}$ of the blood sample will be known.

Blood samples were equilibrated with a known gas ( 12 per cent $\mathrm{O}_{2}$ and 5 per cent $\mathrm{CO}_{2}$ ) previously analyzed by gas chromatography. These tonometered samples were transported in ice to the various areas for analysis.

The results were again analyzed employing the Student " $t$ " test, using the known $\mathrm{Po}_{2}$ and $\mathrm{PCO}_{2}$ of the tonometered sample as the control and comparing the results obtained from each area with these values. 


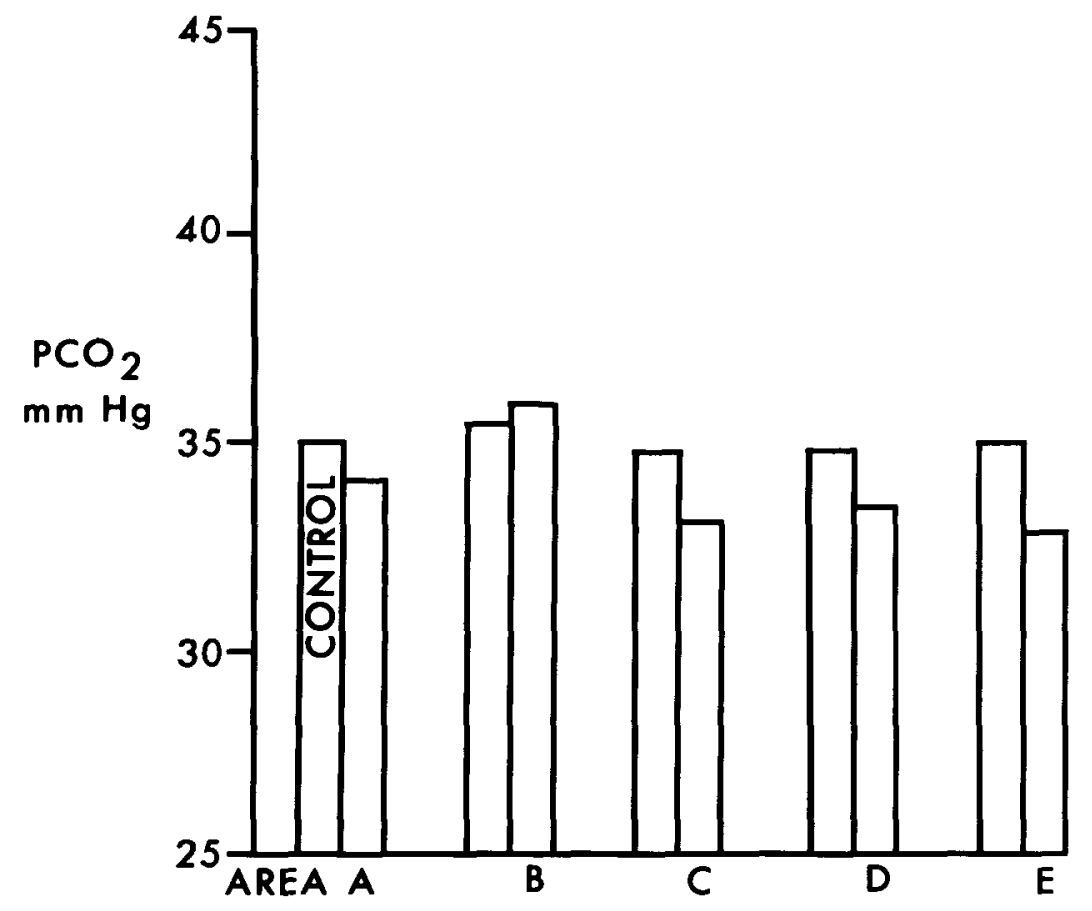

Figure 8. Phase $\mathrm{II}-\mathrm{PCO}_{2}$ values.

\section{RESULTS}

There were no statistically significant differences for $\mathrm{PcO}_{2}$ (Figure 8). The mean $\mathrm{PCO}_{2}$ values now ranged from 32 to $36 \mathrm{~mm} \mathrm{Hg}$. The mean $\mathrm{Po}_{2}$ values continued to show a range from area to area of $11 \mathrm{~mm} \mathrm{Hg}$ (Figure 9). Area $\mathrm{B}$ results for $\mathrm{PO}_{2}$ were significantly lower than control. This could be alleviated somewhat by employing a blood-gas correction factor to readings in this area, which uses gases to calibrate its $\mathrm{Po}_{2}$ electrode. Area $\mathrm{D}$ readings were significantly higher than control values, and reasons for this were not apparent.

\section{Discussion}

From this study, we have shown that in spite of careful attention to detail, the results obtained in blood gas analyses may be inaccurate. The major sources of error occur in two areas:

(1) Obtaining and handling of the blood sample.

(2) Analysis of the sample.

Certain details must be carefully observed in order to prevent errors in obtaining and handling the sample (Table I):

(a) Arterial blood should be used whenever possible, as values from capillary or arterialized venous blood may be inaccurate during low flow states, in newborns during the first 24 hours of life, and often in newborns with respiratory distress syndrome. ${ }^{11,12}$ 


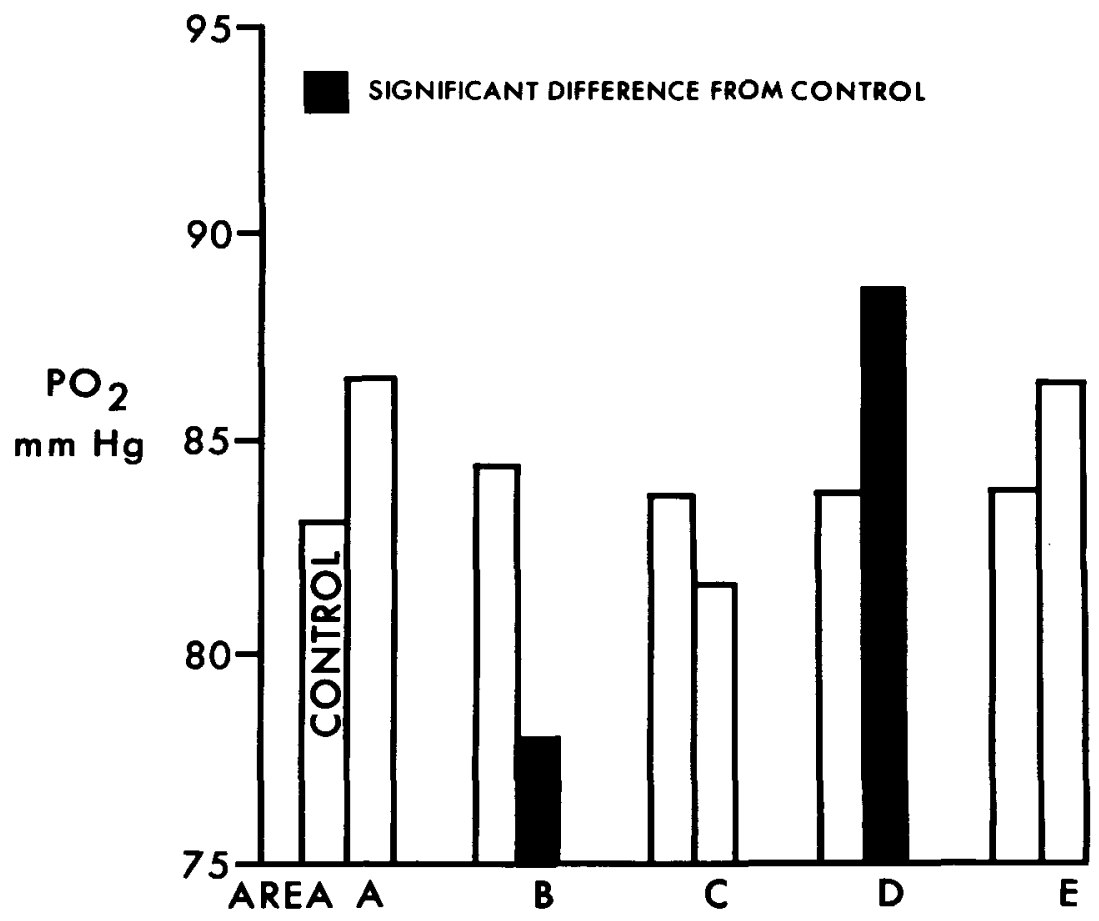

Figure 9. Phase II - $\mathrm{Po}_{2}$ values.

TABLE I

Prevention of Errors in Obtaining

SAMPLE

1. Use arterial blood

2. Glass or plastic syringes may be used

3. Heparin must fill only syringe deadspace

4. Avoid traction on plunger

5. Avoid air bubbles in sample

6. Store in ice until analyzed

(b) Glass or plastic (polypropylene) syringes may be used to collect the sample. However, if any delay in analysis of the sample is anticipated, glass is to be preferred, as the diffusion rate of gases through glass is less than that through plastic. The type of plastic used in manufacture of the syringe may also be important, as the diffusion rate of gases through polypropylene is less than that through polyethylene. If a plastic syringe is used, one must disengage the plunger from the barrel before use, so that arterial blood will flow freely into the syringe during collection. ${ }^{13}$

(c) Heparin should fill only the dead space of the syringe.

(d) One must not use excessive traction on the plunger of the syringe, as this may cause gases to be drawn out of solution and lower gas values. ${ }^{2}$

(e) One must avoid air bubbles in the sample, which will change blood gas values. 
TABLE II

Prevention of Errors in Analysis OF SAMPLE

1. Accurate calibrating methods

2. Apparatus temperature $37 \mathrm{C}$

3. Change membranes frequently

4. Mix sample thoroughly

5. Meter must stabilize before reading

6. Blood gas factor

(f) The sample must be stored in ice until the time of analysis in order to slow the metabolic rate of cellular elements in the sample.

In order to prevent errors in the analysis of the blood sample these points should be observed (Table II):

(a) Accurate calibrating methods must be used for the electrodes. If gases are to be used it must be ensured that these gases have been accurately analyzed prior to use If a liquid is to be used for calibration of the $\mathrm{Po}_{2}$ electrode, it is usually water from the water bath surrounding the electrode system. It must be ensured that the water jacket has been on for a sufficient period of time to warm to $37^{\circ} \mathrm{C}$, and for equilibration with room air to have occurred.

(b) The water jacket surrounding the electrodes must be kept at exactly $37^{\circ} \mathrm{C.} .^{14}$

(c) Faulty membranes or faulty glass electrodes must be replaced.

(d) The blood sample must be thoroughly mixed before aliquots are introduced into the electrodes for analysis.

(e) The electrode meter must be allowed to stabilize before a reading is taken. This is especially important for the $\mathrm{CO}_{2}$ electrode, since, depending upon the thickness of the Teflon membrane, up to three minutes may be required for meter stabilization.

(f) $\mathrm{Po}_{2}$ readings should be corrected upwards by a blood gas factor, on readings from machines which employ gases to calibrate the electrode. ${ }^{9}$

\section{Conclusion}

The results of this study show that significant discrepancies may exist in blood gas values from various areas within a large general hospital. Potential sources of error in blood gas values involve both collection of the sample and its handling before analysis, and factors in the laboratory itself involving both equipment and personnel.

It is important for physicians to realize that, in spite of strict attention to detail, blood gas values may not be accurate, and clinical judgment must always be judiciously employed to interpret the results obtained.

\section{RéSUMÉ}

Cette étude démontre que, malgré une attention minutieuse, l’analyse des gaz du sang peut être erronnée. Les principales sources d'erreur sont de deux ordres. 
(1) Le prélèvement et la manutention de l'échantillon de sang.

(2) L'analyse de l'échantillon.

Il s'impose d'observer soigneusement certains détails pour prévenir des erreurs au cours du prélèvement et de la manutention de l'échantillon (Table I):

(a) Autant que possible, il faut utiliser du sang artériel, car les données du sang capillaire ou du sang veineux artérialisé peuvent être inexactes dans les états où la circulation est lente, chez les nouveaux nés au cours des 24 premières heures de vie et souvent chez les nouveaux nés présentant un syndrome de détresse respiratoire..$^{11,12}$

(b) Pour prélever l'échantillon on peut employer des seringues de verre ou de plastique (polypropyline); toutefois, si l'on prévoit un délai avant l'analyse, une seringue de verre est préférable car le taux de diffusion des gaz à travers le verre est inférieur à celui à travers le plastique. La sorte de plastique utilisé pour faire la seringue est également importante car le taux de diffusion des gaz est inférieur à travers le polypropylene comparé à celui à travers le polyéthylene. Si l'on emploie une seringue de plastique, il est à conseiller d'enlever le piston avant l'usage de façon à ce que le sang artériel coule librement dans la seringue durant le prélèvement. ${ }^{13}$

(c) L'héparine doit combler seulement l'espace mort de la seringue.

(d) Il ne faut pas exercer une traction trop forte sur le piston ce qui pourrait extraire les gaz du sang et donner des résultats inférieurs. ${ }^{2}$

(e) Il faut éviter d'avoir des bulles d'air dans l'échantillon ce qui changerait les valeurs des gas sanguins.

(f) L'échantillon doit être conservé sur la glace jusqu'au moment de l'analyse pour ralentir le métabolisme des cellules dans l'échantillon.

Pour éviter des erreurs dans l'analyse de l'échantillon de sang, il faut observer trois points (Table II):

(a) Il faut utiliser des méthodes précises de calibration des électrodes. Si l'on doit employer des gaz, il faut s'assurer que ces gaz ont été analysés de façon précise avant l'usage. Si l'on emploie un liquide pour calibrer l'électrode de la $\mathrm{Po}_{2}$, il faut employer l'eau du bac qui entoure le systême d'électrode. Il faut s'assurer que le chauffe-eau fonctionne depuis un certain temps pour que la température de l'eau soit à $37^{\circ}$ et qu'elle ait eu le temps de devenir en équilibre avec l'air de la pièce.

(b) Le chauffe-eau autour des électrodes doit être maintenue à $37^{\circ}$ exactement. ${ }^{14}$

(c) Il faut remplacer les membranes et les électrodes défectueuses.

(d) L'échantillon de sang doit être agité et bien mélangé avant l'introduction des électrodes pour analyse.

(e) Le compteur de l'électrode doit avoir le temps de s'arrêter avant qu'une lecture soit faite. Cela devient plus spécialement important pour l'électrode $\mathrm{du} \mathrm{CO}_{2}$ puisque, selon l'épaisseur de la membrane de Teflon, il faut un délai qui peut aller jusqu'à trois minutes avant que le compteur ne se stabilise.

(f) Les lectures de la $\mathrm{Po}_{2}$ doivent être augmentées par un facteur de gaz sanguin à partir des lectures sur les machines qui emploient des gaz pour calibrer les électrodes. ${ }^{9}$ 


\section{Conclusion}

Les résultats de cette étude démontrent que, dans un grand hôpital, il peut exister des différences appréciables entre les valeurs des gaz sanguins d'un endroit à l'autre. Les sources éventuelles d'erreurs dans les valeurs des gaz sanguins impliquent aussi bien le prélèvement que la manutention de l'échantillon avant l'analyse et, dans le laboratoire, elles impliquent aussi bien le matériel que le personnel. Il est bien important pour les médecins de se rappeler que, malgré toute l'attention apportée à la technique, les valeurs des gaz sanguins peuvent être erronnées et que c'est à la lumière du jugement clinique qu'il faut interpréter les résultats obtenus.

\section{REFERENCES}

1. SyKes, M.K. \& Vickers, M.D. Principles of measurement for anaesthetists. Blackwell Scientific Publications. 1970.

2. Adams, A.P., Morgan-Hughes, J.L., \& Sykes, M.K. pH and blood-gas analysis - measurement and sources of error with electrode systems. Anaesthesia 22: 575 (1967).

3. Severinghaus, J.W. et al. Electrodes for $\mathrm{Po}_{2}$ and $\mathrm{PCO}_{2}$. J. Appl. Physiol. 13: 515 (1958).

4. SMIth, A.C. \& HAH, C.E.W. Electrodes for measurement of $\mathrm{O}_{2}$ and $\mathrm{CO}_{2}$ tensions. B. Journ. of Anaes. 41: 731 ( 1969).

5. Scurr, C. \& Feldman, S. Scientific foundations of anaesthesia. William Heinemann Medical Books Ltd. 1970.

6. Adams, A.P., Morgan-Hughes, J.O., \& Sykes, M.K. pH and blood gas analysis: measurement and sources of error using electrode systems. Anaesthesia 23: 47 (1968).

7. Clark, L.C. Monitor and control of tissue oxygen tensions. Trans. Amer. Ooc. Art. Int. Org. 2: 41 (1946).

8. Severinghaus, J.W. Electrodes for $\mathrm{Pco}_{2}, \mathrm{Po}_{2}$ and $\mathrm{PH}$. Acta Anaes. Scand. Suppl. 11: $206(1962)$.

9. Adams, A.P. \& Mongan-Hughes, J.O. Determination of the blood gas factor of the oxygen electrode using a new tonometer. Brit. J. of Anaes. 39: 107 ( 1967).

10. Bach-Simpson Laboratory Equipment Division: Numerical Bulletin \#144. Po $\mathrm{P}_{2}$ measurements.

11. SiggaArd-Andersen, O. Acid-base gas parameters - arterial or capillary? Scand. J. Clin. Lab. Invest. 21 : 289 (1968).

12. Glasgow, J.F.T., FlynN, D.M., \& Swyer, P.R. A comparison of descending aortic and "arterialized" capillary blood in the sick newborn. C.M.A.J. Vol. 106, p. 660 (1972).

13. Evers, W., RACA, G.B., \& LeVY, A.A. A comparative study of plastic (polypropylene) and glass syringes in blood-gas analysis. Anes. and Anal. 51: 92 (1972).

14. Greenderg, A.G. et al. Temperature coefficients for $\mathrm{PCO}_{2}$ and $\mathrm{pH}$ in whole blood. Arch. Surg. (Chicago) 91: 867 (1965). 